\title{
North American wetland mitigation and restoration policies
}

\author{
Royal C. Gardner
}

Received: 13 October 2008/Accepted: 13 October 2008/Published online: 7 November 2008

(C) Springer Science+Business Media B.V. 2008

Like wetlands themselves, the legal and policy regimes that govern wetland mitigation in North America are not static. They have evolved over time, in both Canada and the United States, often encompassing the mitigation sequence or hierarchy of "avoid, minimize, and compensate" (Cox and Grose 2000; Gardner 2005). Yet, the manner in which compensatory mitigation is provided, and its level of effectiveness, varies from jurisdiction to jurisdiction. This special issue of Wetlands Ecology and Management consists of five papers examining different aspects of wetland mitigation and restoration policies. It illustrates the cross-disciplinary focus of the journal, aiming to cover key issues that link wetland science, management, policy, and economics.

The contributing authors have long been involved in developing, applying, and/or studying mitigation policies. Clayton Rubec and Alan Hanson open the special issue by providing an overview of mitigation policies of the 14 jurisdictions in the Canadian federation (its ten provinces, three territories, and the federal government). While some jurisdictions have adopted a "no net loss" policy, others have embraced a stricter "no loss" approach for certain wetlands. For example, New Brunswick is committed to no loss of provincially significant wetland habitat. The authors

R. C. Gardner ( $\square)$

Institute for Biodiversity Law and Policy, Stetson

University College of Law, Gulfport, FL, USA

e-mail: gardner@law.stetson.edu note, however, that Canada lacks an effective means to evaluate the extent to which mitigation contributes to the objective of no net loss of wetland area and functions.

Palmer Hough and Morgan Robertson then provide an extensive history of the development of mitigation policies under the U.S. Clean Water Act. They explain how the mitigation debate now tends to focus on compensatory mitigation, the last step in the sequence, and trace the expansion of mitigation banking and in-lieu fee programs as alternatives to traditional approaches to offset wetland impacts. It is a must-read for anyone who wishes to understand the historical context of the aquatic resources mitigation regulation published by the U.S. Army Corps of Engineers and U.S. Environmental Protection Agency in April 2008 (Department of Defense and Environmental Protection Agency 2008).

The growing reliance on entrepreneurial wetland mitigation banks is a unique feature of U.S. mitigation policy. In the next paper, Morgan Robertson offers two case studies of entrepreneurial wetland mitigation banks, as they attempt to navigate economic, ecological, and regulatory challenges. The reality on the ground can be quite different from the economic theory typically proffered about marketbased environmental policies.

In-lieu fee mitigation is another aspect of U.S. mitigation policy, and Jessica Wilkinson expands upon a 2006 Environmental Law Institute study. She examines 38 in-lieu fee programs and identifies the 
administrative and procedural practices that they will need to adopt to come into compliance with the new federal mitigation regulation. She suggests that if the in-lieu fee programs make these changes, they will likely alleviate past concerns about in-lieu fee mitigation to offset wetland impacts in a timely and efficient manner.

The final paper offers a more global perspective and raises serious questions about mitigation and restoration policies in light of climate change. In a policy paper that incorporates opinion, interpretation, and scientific-based arguments, Kevin Erwin discusses the need for restoration practitioners to take climate change impacts into account when designing projects. He also points out how restoration projects can be a component of climate change mitigation and adaptation strategies.

I would like to thank everyone who has contributed to this special issue, especially the Editor in Chief Hans Gottgens for his guidance and advice. I would also like to express my appreciation to the many reviewers for their careful evaluation of the manuscripts: Richard Ambrose, Paul Boudreaux, Patricia Farnese, Palmer Hough, Steve Johnson, Mark Latham, George Lukacs, Steven Martin, Jim May, Rob McInnes, Randy Milton, Irma Russell, Margaret Strand, and Douglas Williams.
Debates about mitigation and restoration policies are not confined to North America, of course. Indeed, a workshop held at the IUCN World Conservation Congress in Barcelona in October 2008 has sparked an effort to build a consensus for a global approach to wetland mitigation that incorporates an "avoid, minimize, and offset" sequence, and the Ramsar Scientific and Technical Review Panel is recommending that wetland restoration be a thematic area for its work in the next triennium. It is hoped that the papers in this volume will provide lessons that will illuminate such discussions.

\section{References}

Cox K, Grose A (2000) Wetland mitigation in Canada: a framework for application. North American Wetlands Conservation Council, Ottawa

Department of Defense and Environmental Protection Agency (2008) Compensatory mitigation for losses of aquatic resources; final rule. Fed Regist 73:19593-19705

Gardner R (2005) Mitigation. In: Connolly KD, Johnson S, Williams D (eds) Wetlands law and policy: understanding Sect. 404. American Bar Association, Chicago 